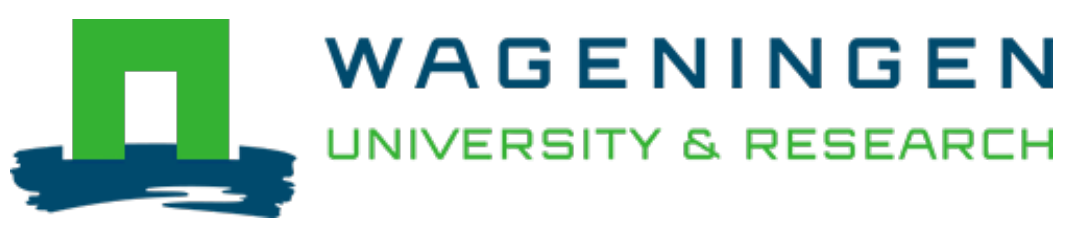

\title{
Fertilization changes soil microbiome functioning, especially phagotrophic protists
}

\author{
Soil Biology and Biochemistry \\ Zhao, Zhi Bo; He, Ji Zheng; Quan, Zhi; Wu, Chuan Fa; Sheng, Rong et al \\ https://doi.org/10.1016/j.soilbio.2020.107863
}

This article is made publicly available in the institutional repository of Wageningen University and Research, under the terms of article $25 \mathrm{fa}$ of the Dutch Copyright Act, also known as the Amendment Taverne. This has been done with explicit consent by the author.

Article 25 fa states that the author of a short scientific work funded either wholly or partially by Dutch public funds is entitled to make that work publicly available for no consideration following a reasonable period of time after the work was first published, provided that clear reference is made to the source of the first publication of the work.

This publication is distributed under The Association of Universities in the Netherlands (VSNU) 'Article $25 \mathrm{fa}$ implementation' project. In this project research outputs of researchers employed by Dutch Universities that comply with the legal requirements of Article $25 \mathrm{fa}$ of the Dutch Copyright Act are distributed online and free of cost or other barriers in institutional repositories. Research outputs are distributed six months after their first online publication in the original published version and with proper attribution to the source of the original publication.

You are permitted to download and use the publication for personal purposes. All rights remain with the author(s) and / or copyright owner(s) of this work. Any use of the publication or parts of it other than authorised under article $25 \mathrm{fa}$ of the Dutch Copyright act is prohibited. Wageningen University \& Research and the author(s) of this publication shall not be held responsible or liable for any damages resulting from your (re)use of this publication.

For questions regarding the public availability of this article please contact openscience.library@wur.nl 


\title{
Fertilization changes soil microbiome functioning, especially phagotrophic protists
}

\author{
Zhi-Bo Zhao $^{\text {a,b }}$, Ji-Zheng He ${ }^{\text {a,b,c, }}$, Zhi Quan ${ }^{\mathrm{d}}$, Chuan-Fa Wu ${ }^{\mathrm{a}, \mathrm{e}}$, Rong Sheng ${ }^{\mathrm{f}}$, Li-Mei Zhang ${ }^{\mathrm{a}, \mathrm{b}}$, \\ Stefan Geisen ${ }^{\mathrm{g}, \mathrm{h}, * *}$ \\ ${ }^{a}$ State Key Laboratory of Urban and Regional Ecology, Research Center for Eco-Environmental Sciences, Chinese Academy of Sciences, Beijing, 100085, China \\ ${ }^{\mathrm{b}}$ University of Chinese Academy of Sciences, Beijing, 100049, China \\ ${ }^{\mathrm{c}}$ Faculty of Veterinary and Agricultural Sciences, The University of Melbourne, Parkville, VIC, 3010, Australia \\ d CAS Key Laboratory of Forest Ecology and Management, Institute of Applied Ecology, Chinese Academy of Sciences, Shenyang, 110016, China \\ ${ }^{\mathrm{e}}$ College of Resource and Environmental Sciences, Henan Agricultural University, Zhengzhou, 450002, China \\ ${ }^{\mathrm{f}}$ Key Laboratory of Agro-ecological Processes in Subtropical Regions and Taoyuan Station of Agro-Ecology Research, Institute of Subtropical Agriculture, Chinese \\ Academy of Sciences, Changsha, 410125, China \\ ${ }^{\mathrm{g}}$ Department of Terrestrial Ecology, Netherlands Institute of Ecology NIOO-KNAW, 6708, PB Wageningen, the Netherlands \\ ${ }^{\mathrm{h}}$ Laboratory of Nematology, Wageningen University \& Research, 6700, ES Wageningen, the Netherlands
}

\section{A R T I C L E I N F O}

\section{Keywords:}

Phagotrophic protists

Microbiome functioning

Fertilization

Nitrogen

High-throughput sequencing

\begin{abstract}
A B S T R A C T
The soil microbiome determines crop production and drives nutrient cycling, functions that are altered by fertilization. Yet, we have only begun to understand the effects of fertilization on taxonomic changes on soil microorganisms, while impacts on functional groups across the microbiome and therefore potential soil functioning have never been assessed. Here, using a range of methods including high-throughput sequencing, we identified 77 functional parameters of the main microbiome groups including bacteria, fungi, and protists in three common agricultural soil types in China (black, fluvo-aquic, and red soil), which were fertilized in the same way over two years. We show that fertilization most strongly and generally throughout soil types reduced the relative abundance of the main microbial predators, phagotrophic protists, by $31 \%$. Ten functional groups within the microbiome showed soil type-specific responses to fertilization. For example, ammonia-oxidizing bacteria, and predatory/exoparasitic bacteria were reduced by fertilization in the acidic black and the red soils, while, no other microbial functional group than phagotrophic protists was suppressed by fertilization in the alkaline fluvoaquic soil. The significant reductions in microbial functional groups especially in acidic soils could be explained by nitrogen enrichment, increased soil acidification and potential biotic links between the functional groups within the microbiome. Together, we show that the fertilization-induced abiotic changes alter microbial functions that depend on the soil and environmental conditions. Particularly the most profound changes on the group of microbial predators might subsequently affect other soil functions performed by bacteria and fungi.
\end{abstract}

\section{Introduction}

Agroecosystems are crucial for food and feed provisioning across the world (Lal, 2004; Hartman et al., 2018). Especially heavily managed agroecosystems are suggested to be needed to meet the increasing global demand of crop production (Tilman et al., 2002, 2011). Fertilization is a common and effective solution to increase yields (Tilman et al., 2002; Kuypers et al., 2018), but the application of fertilizers over a long time-span has many negative side-effects on ecosystem functioning and services. Among them are climate change-facilitating greenhouse gas emissions, water eutrophication- and soil acidification-causing nitrate leaching and increases of soil-borne pests, which together lead to long-term crop yield decreases (Horrigan et al., 2002; Altieri and Nicholls, 2003; Erisman et al., 2013). However, many agriculture-induced losses of soil functioning and services are due to negative effects of fertilization on the soil microbiome.

\footnotetext{
* Corresponding author. State Key Laboratory of Urban and Regional Ecology, Research Center for Eco-Environmental Sciences, Chinese Academy of Sciences, Beijing, 100085, China.

$* *$ Corresponding author. Laboratory of Nematology, Wageningen University \& Research, 6700, ES Wageningen, the Netherlands.

E-mail addresses: jzhe@rcees.ac.cn (J.-Z.He), stefan.geisen@wur.nl (S. Geisen).
} 
The soil microbiome, including bacteria, archaea, fungi, protists and viruses, plays crucial roles in agricultural ecosystems as catalyzers of nutrient cycling, such as carbon sequestration (Yuan et al., 2012), ammonia oxidation (Prosser and Nicol, 2012), and phosphorus transformation (Parniske, 2008; Richardson et al., 2009). These microbial processes substantially affect soil fertility and consequently support crop production (Widder et al., 2016; Fierer, 2017; Jiao et al., 2019). However, we still know surprisingly little about the precise functional role of the soil microbiome in agricultural systems (Wild, 2016), at least partly due to its high diversity and complexity. Previous studies illustrated that microbial diversity is linked to soil multifunctionality (Wagg et al., 2014; Delgado-Baquerizo et al., 2016; Valencia et al., 2018; Li et al., 2019), but diversity is not always linked to functioning (Shade, 2017). Furthermore, these and other studies focused on some parts of the microbiome, particularly bacteria and fungi. Few studies have included other microorganisms such as phagotrophic protists, which are key microbiome predators that regulate microbiome structure and contribute to element cycling in soil (Geisen et al., 2018; Thakur and Geisen, 2019).

Fertilization affects the taxonomic composition of all these microbial groups including bacteria (Zeng et al., 2016), fungi (Allison et al., 2007), and protists (Zhao et al., 2019). However, much less is known on how fertilization changes functional groups in the microbiome that is directly linked to soil functioning (Wessen and Hallin, 2011; Zhu et al., 2018). Previous studies have revealed susceptibility of single functional groups within the microbiome to fertilization, such as ammonia-oxidizing bacteria (AOB) (He et al., 2007; Shen et al., 2008). Also phagotrophic protists as assessed by cultivation-based methods were shown to be affected (Angus et al., 2014). As such, fertilization might change the structure of the soil microbiome through altering trophic food-web interactions (Geisen et al., 2018), including species-specific predation-induced changes in microbiome community structure (Schulz-Bohm et al., 2017; Thakur and Geisen, 2019) and functioning (Saleem and Moe, 2014). Furthermore, previous studies illustrated that trophic levels within the biodiversity in soil responded differently to environmental disturbances (Hedlund et al., 2004; Wang et al., 2019a), with potentially stronger effects on larger organisms according to the trophic sensitivity hypothesis (Petchey et al., 1999; Voigt et al., 2003; Cheng et al., 2017). Yet, if this concept established for macroscopic organisms holds at the microbiome level remains unknown.

Here, we aimed to understand the impact of fertilization on microbiome functioning in three agriculturally managed soil types that received the same nitrogen fertilization regime over 2 years. We performed an unprecedented classification of microbial functional groups including functional annotation of taxonomic information retrieved by high-throughput sequencing of diverse microbial groups, quantitative PCR, phospholipid fatty acids analyses, and microbial activity assays. We tested the hypothesis that nitrogen fertilization changed the functional composition of the soil microbiome and reduces microbial functioning across the three soil types. Furthermore, we hypothesized that the responses of microbial functioning to fertilization vary between soil types due to differences in soil properties.

\section{Materials and methods}

\subsection{Field site management and soil sampling}

The field experimental sites were located in Gongzhuling (GZL, $43^{\circ} 29^{\prime} \mathrm{N}, 124^{\circ} 47^{\prime} \mathrm{E}$, a black soil (Mollisols)), Xuchang (XC, $34^{\circ} 2^{\prime} \mathrm{N}$, $113^{\circ} 51^{\prime} \mathrm{E}$, a fluvo-aquic soil (Calcaric cambisol)), and Taoyuan (TY, $28^{\circ} 54^{\prime} \mathrm{N}, 111^{\circ} 29^{\prime} \mathrm{E}$, a red soil (Ultisol)). These locations span a large latitudinal gradient and cover the main agriculturally used soil types in China. Each field site was uniformly treated with three fertilization treatments consisting of no nitrogen addition (control), nitrogen addition alone $(\mathrm{N})$, and nitrogen addition plus straw amendment $(\mathrm{N}+$ Straw) in randomized triplicate plots since 2015. Each year before sowing, phosphorus (120 kg ha $\left.{ }^{-1} \mathrm{P}_{2} \mathrm{O}_{5}\right)$ and potassium $\left(120 \mathrm{~kg} \mathrm{ha}^{-1} \mathrm{~K}_{2} \mathrm{O}\right)$ were added to each plot at the same dose. Urea was applied at a rate of $200 \mathrm{~kg}$ $\mathrm{ha}^{-1}$ nitrogen. Dry maize straw from the last harvest was cut into $2-3 \mathrm{~cm}$ length and amended at a rate of $5000 \mathrm{~kg} \mathrm{ha}^{-1}$. The same fertilizer form was applied across all three field sites, and maize was grown as the main food crop in summer and autumn.

Soils were sampled after two years of fertilization at the maize heading stage in summer 2016. The soil sample was a composite of five cores randomly collected in 5-10 cm depth. The top $5 \mathrm{~cm}$ soil layer was discarded. The diameter of each soil corer is $10 \mathrm{~cm}$. In total, 27 soil samples were gathered and brought to the laboratory on ice immediately. Soils were sieved through a $2 \mathrm{~mm}$ diameter mesh, and remaining fine roots and straw residues were manually removed. Subsamples were taken and stored for physicochemical properties at $4{ }^{\circ} \mathrm{C}$ and for molecular analyses at $-80^{\circ} \mathrm{C}$ until use. More details on the management of the sites and sampling are provided in (Zhao et al., 2019).

\subsection{Soil physicochemical properties and climatic parameters collection}

Soil physicochemical properties were analyzed as described in (Zhao et al., 2019). In short, soil pH was measured in 1:2.5 soil/water suspension and moisture by the loss of weight after oven drying to constant weight. Total carbon and nitrogen (TC, TN) were determined by an elemental analyzer. The $\mathrm{K}_{2} \mathrm{Cr}_{2} \mathrm{O}_{7}-\mathrm{H}_{2} \mathrm{SO}_{4}$ oxidation-reduction colorimetric method was used to measure soil organic carbon (SOC). Dissolved organic carbon (DOC) was extracted by $0.5 \mathrm{M} \mathrm{K}_{2} \mathrm{SO}_{4}$, and $\mathrm{NH}_{4}^{+} \mathrm{N}$ and $\mathrm{NO}_{3}^{-}-\mathrm{N}$ were extracted by $1 \mathrm{M} \mathrm{KCl}$. Total phosphorus (TP) was determined by sodium hydroxide digestion-Mo Sb anti spectrophotometrics (Dick and Tabatabai, 1977). Available phosphorus (available P) was extracted by $\mathrm{NaHCO}_{3}$ and measured by molybdenum blue colorimetry (Liang et al., 2014). To compare differences in nitrification processes across soil types, potential nitrification rate (PNR) was analyzed by the chlorate inhibition method (He et al., 2007). Precipitation was determined for 90 days before sampling from the National Meteorological Information Center of China (http://data.cma.cn/). Solar radiation was determined for 3 days before sampling using data provided by NASA Langley Research Center (LaRC) POWER Project (https://power.larc.nasa.gov/data-access-viewer/).

\subsection{Soil DNA extraction}

Total DNA was extracted from $0.4 \mathrm{~g}$ soil using the PowerSoil DNA Isolation Kit (MO BIO laboratories, Carlsbad, USA) according to the manufacturer's protocol. NanoDrop Spectrophotometry (NanoDrop Technologies Inc., Wilmington, DE, USA) was used to measure and ensure sufficient DNA quantity and quality for subsequent analyses.

\subsection{PCR assays and high-throughput sequencing}

The extracted soil total DNA samples were amplified by three metabarcoding primer sets (F-515/R-806, F-817/R-1196, F-TAReuk454FWD1/R-TAReukREV3), targeting a roughly 291 bp region of the 16S rRNA gene for bacteria (Bates et al., 2011), a 379 bp region of the 18S rRNA gene for fungi (Rousk et al., 2010) and a 418 bp region of the 18S rRNA gene for all eukaryotes (Stoeck et al., 2010). In order to ensure that the reaction systems were not contaminated, negative control samples that without addition of DNA were run in each PCR assay. Detailed descriptions of the PCRs are found in (Zhao et al., 2019). PCR amplicons were extracted from $2 \%$ agarose gels and purified using an AxyPrep DNA Gel Extraction Kit (Axygen Biosciences, Union City, CA, USA) according to the manufacturer's instructions and quantified by QuantiFluor ${ }^{\mathrm{TM}}$-ST (Promega, USA). Purified amplicons were pooled in equimolar ratios and sent for sequencing on an Illumina MiSeq PE 300 sequencer (Majorbio Bio-Pharm Technology Co. Ltd., Shanghai, China). 


\subsection{Bioinformatics for functional composition of the soil microbiome}

The taxonomic assignments of the soil microbiome were performed in QIIME 1.90 (Caporaso et al., 2010). Briefly, raw sequences were merged to paired-end reads, barcodes were removed, sequences demultiplexed and quality filtered including the removal of chimeras. Operational Taxonomic Units (OTU) were clustered at 97\% sequence similarity in UPARSE (Edgar, 2013). SILVA (version_123) (Quast et al., 2013) was used for taxonomic annotations of bacterial and fungal OTUs, while the Protist Ribosomal Reference (PR2) database (version_4.5) (Guillou et al., 2013) was used to taxonomically assign protist OTUs. A minimum similarity cutoff at $90 \%$ was used for conservative OTU assignments. Obtained sequences were rarefied to 41,359 for bacteria, 37, 002 for fungi, and 36,242 for eukaryotes that include protists. Ambiguous taxa were discarded, taxa assigned as archaea were filtered out from the bacterial OTU table, while multicellular eukaryotes, Rhodophyta, Streptophyta, Fungi, Opisthokonta_X, and Metazoa were excluded to obtain the protist-only OTU table from the microeukaryotic sequencing approach. The taxonomic OTU tables were annotated to the Functional Annotation of Prokaryotic Taxa (FAPROTAX) (Louca et al., 2016) and fungi functional guild (FunGuild) (Nguyen et al., 2016), to acquire the putative functional composition of bacterial and fungal communities. Protist functional groups were manually assigned. Finally, the soil microbiome can be functionally classified into the main processes in carbon, nitrogen, and sulfur biogeochemical cycling, trophic mode types, and pathogens.

\subsection{Quantitative PCR assay for targeting group and gene of functionally important microorganisms}

Selected group of presumably functionally important microbiome member and its functional gene was targeted using qPCR approach. For that, we selected Chlorophyta as they are the most abundant phototrophic protistan group in soils (Fig. S2). A previous study demonstrated that soil algae including Chlorophyta can be a main source for soil organic matter formation and can promote soil regeneration (Rahmonov et al., 2015). Therefore, Chlorophyta can act as a synonym for soil microbial photosynthesis/carbon fixation capacity as all Chlorophyta are obligate phototrophs. Primer pair used was F-EUK528 and R-CHL002 targeting Chlorophyta (Zhu et al., 2005). qPCR reaction was conducted in $20 \mu \mathrm{l}$ mixtures including $10 \mu \mathrm{l} 2 \times$ Supermix (Bio-rad, USA), $0.5 \mu \mathrm{l}$ BSA, $0.5 \mu \mathrm{l}$ of each primer $(10 \mu \mathrm{M}), 2 \mu \mathrm{l}$ 5-fold diluted DNA (1-10 ng) and $6.5 \mu \mathrm{l}$ of sterilized $\mathrm{ddH}_{2} \mathrm{O}$. The thermocycling condition for Chlorophyta was set according to a previous study (Zhu et al., 2005). Negative controls were included in each reaction by replacing the DNA template with sterilized $\mathrm{ddH}_{2} \mathrm{O}$. Standard curve was generated by ten-fold serial dilutions of a known copy number of the plasmid DNA amplified by qPCR in triplicate, with the plasmid being prepared as previously described (He et al., 2007). The specificity of each reaction was checked by agarose gel electrophoresis and melting curve analysis. The amplification efficiency for Chlorophyta was $89 \%$, and the correlation coefficient $\left(R^{2}\right)$ of standard curve was $>0.99$.

\subsection{Phospholipid fatty acids (PLFA) assays}

Arbuscular mycorrhizal fungi (AMF) are common plant mutualists and plant-beneficial providers of especially phosphorus and water (Parniske, 2008; van der Heijden et al., 2008; Richardson et al., 2009), can reflect the status of nutrients and water in soil. For that, lipids were extracted from $3.600 \mathrm{~g}$ freeze dried soil as described previously (Pan et al., 2016). Soil samples were shaken in a mixture of chloroform-methanol-citrate buffer $(0.15 \mathrm{M}, \mathrm{pH} 4.0)$ at a ratio of $1: 2$ : $0.8(\mathrm{v}: \mathrm{v}: \mathrm{v})$ for $2 \mathrm{~h}$ in the dark. The phospholipids were fractionated from neutral and glycolipids on a silicic acid column, followed by mild alkaline methanolysis to produce fatty acid methyl esters (FAMEs). Methylnonadecanoate (19:0) was added as an internal standard marker.
A gas chromatograph equipped with a flame ionization detector (GC-FID, Agilent Technologies, USA) and MIDI database (Sherlock 6.0, MIDI Inc., USA) was used for separation, detection and notation of FAMEs. The PLFA 16:1 $\omega 5 \mathrm{c}$ was used as a proxy to quantify AMF biomass (Drigo et al., 2010).

\subsection{Statistics}

Statistical analyses were performed in R (3.3.1). The relative abundance of each functional group was depicted in a heatmap (packages: pheatmap). In addition, logarithm transformation was done after multiplying the raw data by $1 \times 10^{5}$ to display differences in fertilization treatments and soil types in the heatmap. For easier visualization and to focus on the presumably major functional groups, the 20 most abundant bacterial, the 8 fungal and all protist functional groups are depicted in the heatmap. Hierarchical clustering was used to compare the overall functional similarity of the soil microbiome in each treatment based on Pearson distance. One-way ANOVA was used to compare differences in soil physicochemical properties, functional groups of the soil microbiome, the absolute abundance of Chlorophyta, potential nitrification rate (PNR), and the biomass of AMF among soil types and fertilization treatments (packages: agricolae, car). Statistical differences were considered significant at $P<0.05$. Duncan post hoc test was used to assess treatment differences in one-way ANOVA analyses. Permutation multivariate analysis of variance (PERMANOVA) was employed to evaluate the significance of factors that influencing soil physicochemical properties and the functional composition of the soil microbiome, which included soil type, fertilization treatment and their interactive effects (packages: vegan, adonis function) (Bell et al., 2014). Due to the large dataset of environmental factors (including $\mathrm{pH}$, moisture, TC, TN, TP, SOC, DOC, $\mathrm{NH}_{4}^{+}-\mathrm{N}, \mathrm{NO}_{3} \mathrm{~N}$, available $\mathrm{P}$, solar radiation, precipitation and latitude), random forest analysis was used to identify the key environmental factors that explained differences in functional groups (packages: rfPermute). The importance of each environmental variable was computed for the average of 5000 trees and determined by an increase in the mean square error (InMSE) (Breiman, 2001; Delgado-Baquerizo et al., 2017; Li et al., 2019). Canonical correspondence analysis (CCA) was used to display positive or negative relationship between the relative abundance of soil microbial functional groups and environmental factors (packages: vegan) (Long et al., 2012). One-way ANOVA revealed one microbial functioning (phagotrophic protists) and one abiotic factor $\left(\mathrm{NH}_{4}^{+}-\mathrm{N}\right)$ were significantly responded $(P<0.05)$ to nitrogen fertilization in the alkaline fluvo-aquic soil, while five variables $\left(\mathrm{pH}, \mathrm{NO}_{3}^{-}-\mathrm{N}\right.$, $\mathrm{AOB}$, predatory/exoparasitic bacteria, and phagotrophic protists) that were significantly changed $(P<0.05)$ by nitrogen fertilizers in the acidic black and red soils. These variables were included in a structural equation model (SEM) to quantify the complex effects of abiotic factors and biotic factors on the significant changes of microbial functional groups in response to nitrogen fertilizations in both the black and red soils. In order to increase the power to the SEM, the a priori theoretical model was constructed based on variables that were significantly changed $(P<0.05)$ by nitrogen fertilizers in both the black and red soils (Delgado-Baquerizo et al., 2016). All of the variables were standardized by $Z$ transformation (mean $=0$, standard deviation $=1$ ) to improve normality (scale function). Based on current microbial food web knowledge, an a priori theoretical model was constructed by assuming that (i) an enrichment of $\mathrm{NO}_{3}^{-}-\mathrm{N}$ by nitrogen fertilization directly induces soil $\mathrm{pH}$ decreases; (ii) an enrichment of $\mathrm{NO}_{3}^{-}-\mathrm{N}$ by nitrogen fertilization directly influences the relative abundance of AOB, predatory/exoparasitic bacteria and phagotrophic protists; (iii) a decrease of soil $\mathrm{pH}$ directly influences the relative abundance of $\mathrm{AOB}$, predatory/exoparasitic bacteria and phagotrophic protists, respectively; (iv) a change of AOB directly influences its predators (predatory/exoparasitic bacteria, and phagotrophic protists) through bottom-up interactions; (v) a change of predatory/exoparasitic bacteria directly influences its predators (phagotrophic protists). The pairwise correlation among these 
variables was calculated by Mantel test (packages: Ecodist) and a covariance matrix of these variables was included for SEM analysis in AMOS 17.0 (SPSS, Chicago, IL, USA). Maximum likelihood estimation was used to fit the covariance matrix to the model (Wang et al., 2016). The $a$ priori theoretical model was adjusted according to the principle of the low Chi-square $\left(\chi^{2}\right)$, nonsignificant probability $(P>0.05)$, high goodness-of-fit-index (GFI > 0.90), low Akaike information criteria (AIC) and root mean square error of approximation (RMSEA $<0.05)$ to ensure that the final model was adequately fitted (Grace and Keeley, 2006).

\subsection{Accession numbers}

The sequencing reads of the bacterial 16S rRNA gene, fungal $18 \mathrm{~S}$ rRNA gene and protist 18S rRNA gene were deposited in the Sequence Read Archive of NCBI under the accession number PRJNA498197(SAMN10284994- SAMN10285020), PRJNA498206 SAMN10285133- SAMN10285159) and PRJNA498211 (SAMN10285206- SAMN10285232), respectively.

\section{Results}

\subsection{Fertilization effects on soil physicochemical properties}

Soil type was the prominent factor that differentiated soil physicochemical properties $\left(R^{2}=0.834, P=0.001\right.$, Table $\left.S 2\right)$. For instance, the black and red soils were acidic, while the fluvo-aquic soil was alkaline (Table S1, Fig. 1). The fluvo-aquic soil had the lowest values of TC, TN, SOC, DOC, available P and moisture, but highest TP among the three soil types $(P<0.05$, Table S1). Fertilization did not significantly affect the overall soil physicochemical properties across the three soil types $\left(R^{2}=\right.$ $0.017, P=0.375$, Table S2). Some abiotic factors were, however, changed by fertilization such as increasing $\mathrm{NO}_{3}^{-}-\mathrm{N}(P<0.05$, Fig. 1b) and $\mathrm{NH}_{4}^{+}-\mathrm{N}(P<0.05$, Fig. 1c).

In comparison to the control, $\mathrm{pH}$ was significantly decreased in the $\mathrm{N}$ + Straw (nitrogen plus straw addition) treatment in the black soil, and by the $\mathrm{N}$ and $\mathrm{N}+$ Straw treatments in the red soil $(P<0.05$, Fig. $1 \mathrm{a}$, Table S1). The concentration of $\mathrm{NO}_{3}^{-}-\mathrm{N}$ was significantly increased in the $\mathrm{N}$ and $\mathrm{N}+$ Straw treatments in the black and red soils $(P<0.05$, Fig. 1b, Table S1). The content of $\mathrm{NH}_{4}^{+}-\mathrm{N}$ was significantly increased in the $\mathrm{N}+$ Straw treatment in the fluvo-aquic soil $(P<0.05$, Fig. $1 \mathrm{c}$, Table S1).

\subsection{Responses of microbial functional groups to fertilization}

In total, 77 functional groups within all soil microbiomes were identified by high-throughput sequencing, including 59 bacterial, 12 fungal, and 6 protist functional groups (Fig.S1).

After two-years of consistent nitrogen fertilizations, the functional composition of the soil microbiome was significantly changed by fertilization across the three soil types $\left(R^{2}=0.079, P=0.007\right.$, Table S2). However, only phagotrophic protists significantly responded to nitrogen fertilizations and decreased in relative abundance (N: $25.67 \%, \mathrm{~N}+$ Straw: $35.64 \%)$ across all three soil types $(P<0.05$, Fig. $2 \mathrm{k})$. The little overall effects of fertilization on microbial functional groups could be attributed to the fact that the functional composition of the soil microbiome was strongly structured by soil type $\left(R^{2}=0.687, P=0.001\right.$, Table S2; Fig. S1). Nitrifying bacteria were relatively more abundant in the fluvo-aquic $(0.142 \pm 0.024)$ than in the black $(0.025 \pm 0.011)$ and the red soil $(0.053 \pm 0.034, P<0.05$, Fig. S2a). Phototrophic protists were higher in the red $(0.506 \pm 0.110)$ than in the fluvo-aquic $(0.162 \pm$ $0.065)$ and the black soil $(0.126 \pm 0.057, P<0.05$, Fig. S2d). AMF were more abundant in the fluvo-aquic $(0.034 \pm 0.013)$ than in the black $(0.003 \pm 0.001)$ and the red soil $(0.018 \pm 0.011, P<0.05$, Fig. S2g).

We detected eleven functional groups within the soil microbiomes retrieved by high-throughput sequencing that significantly responded to
(a)
$\mathrm{pH}$
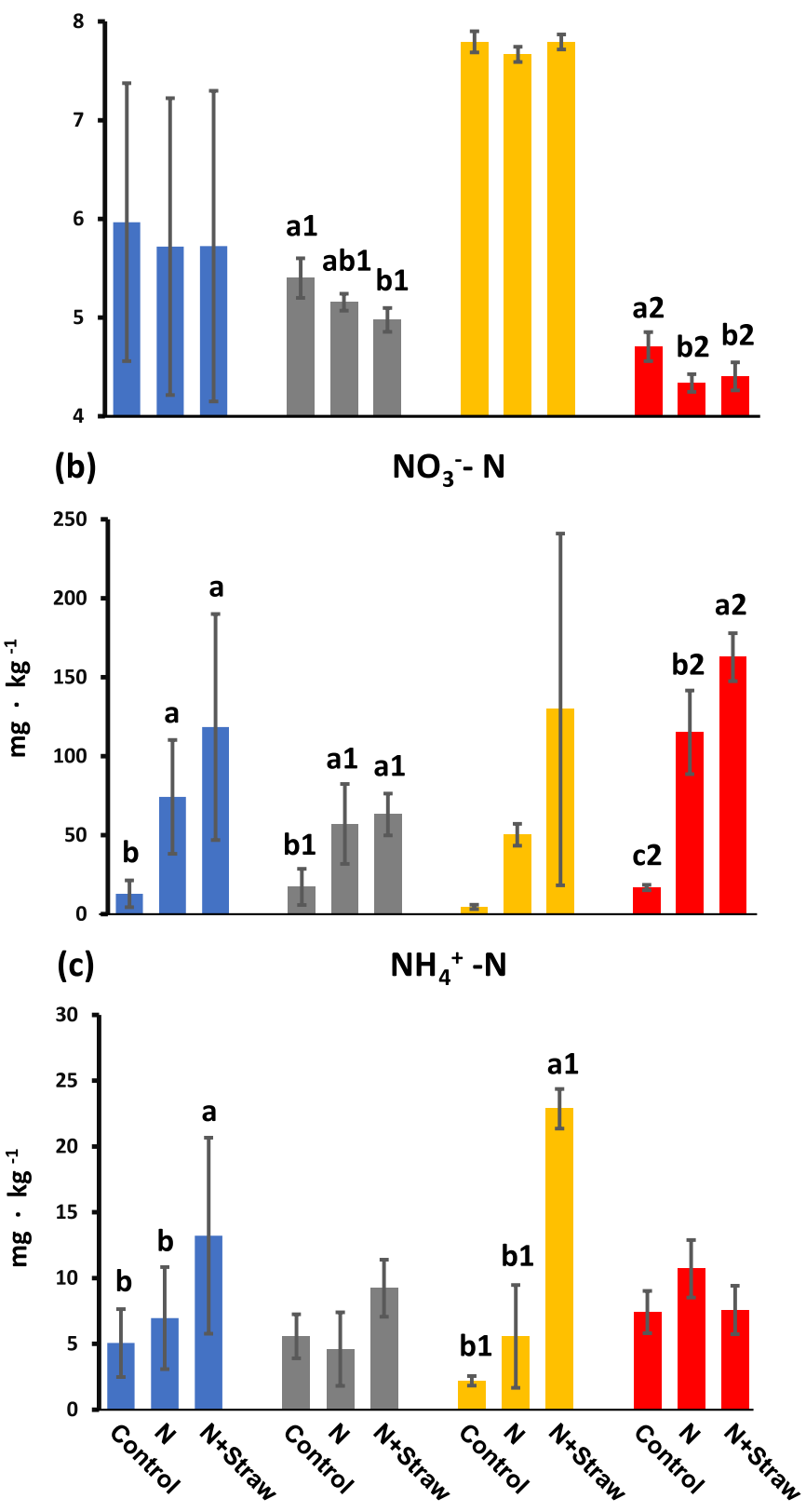

All soil types Black soil Fluvo-aquic soil Red soil

Fig. 1. Effects of fertilization on soil physicochemical properties. Differences in soil physicochemical properties between fertilization treatments in all soils together and in each soil type individually were tested by a one-way ANOVA ( $P$ $<0.05$ ). A digit behind the letter is used to distinguish different comparison groups. Control: no nitrogen addition; N: Nitrogen addition; N + Straw: Nitrogen plus straw addition.

the application of nitrogen fertilizers within a soil type ( $P<0.05$, Fig. 2$)$. Aerobic ammonia oxidation bacteria (AOB) were decreased by the $\mathrm{N}$ and $\mathrm{N}+$ Straw treatments in the black soil and decreased by the $\mathrm{N}$ treatment in the red soil $(P<0.05$, Fig. $2 a)$. Nitrifying bacteria were decreased by the $\mathrm{N}$ and $\mathrm{N}+$ Straw treatments in the black soil $(P<0.05$, Fig. $2 \mathrm{~b})$. All chemoheterotrophy and aerobic chemoheterotrophy bacteria were increased by the $\mathrm{N}$ and $\mathrm{N}+$ Straw treatments in the black soil $(P<0.05$, Fig. $2 \mathrm{c}$ and d). Animal parasitic or mutualistic bacteria were decreased by the $\mathrm{N}$ and $\mathrm{N}+$ Straw treatments in the black soil $(P<0.05$, Fig. $2 \mathrm{e})$. Predatory/exoparasitic bacteria were decreased by the $\mathrm{N}$ and $\mathrm{N}+\mathrm{Straw}$ 
(a) Aerobic ammonia oxidation (AOB)

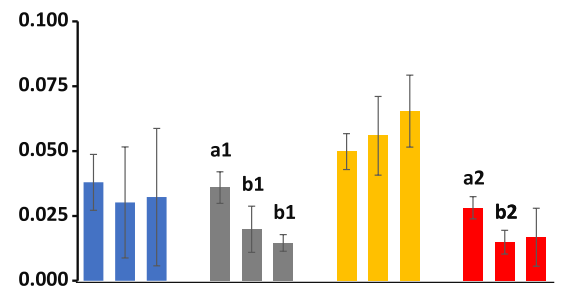

(d) Aerobic chemoheterotrophy

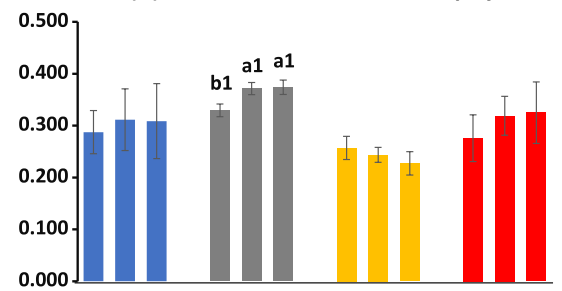

(g) Human pathogens pneumonia

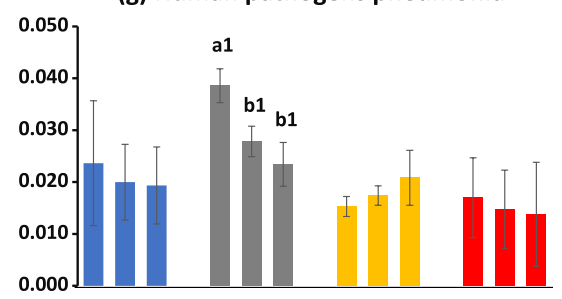

(j) Symbiotroph

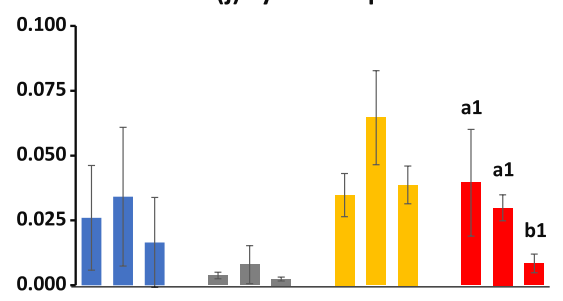

(m) Chlorophyta (qPCR)

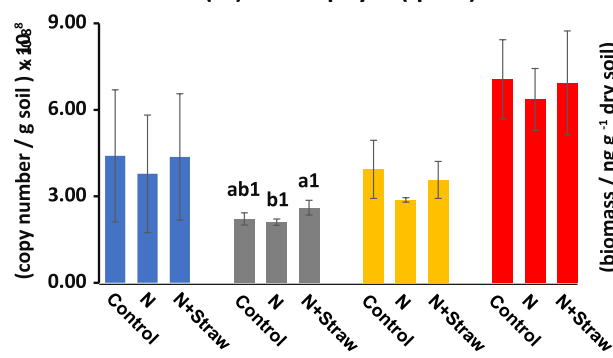

All soil types Black soil Fluvo-aquic soil Red soil (b) Nitrification

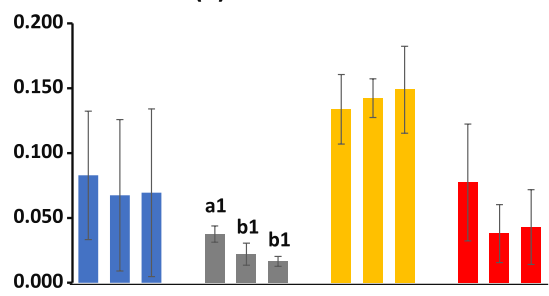

(e) Animal parasites or symbionts

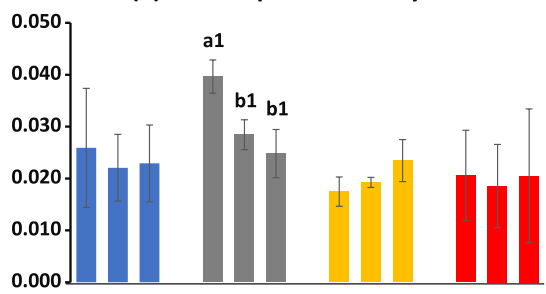

(h) Human pathogens all

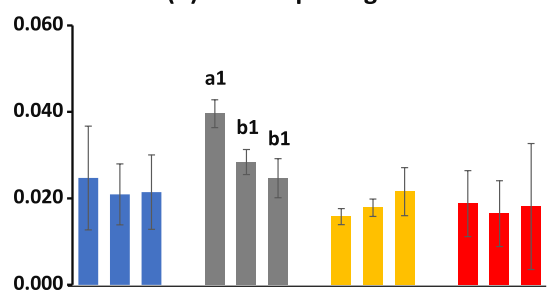

(k) Phagotroph

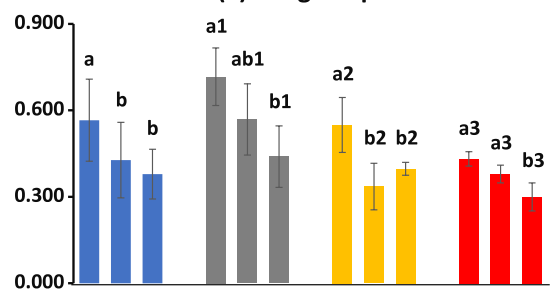

(n) AMF (PLFA) (c) Chemoheterotrophy

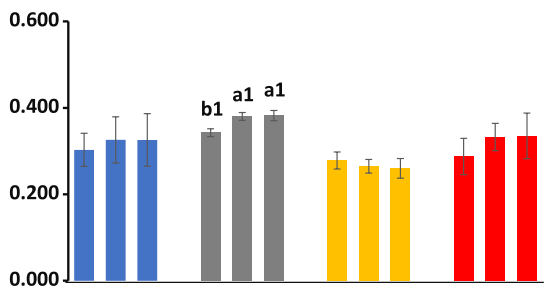

(f) Predatory / exoparasitic

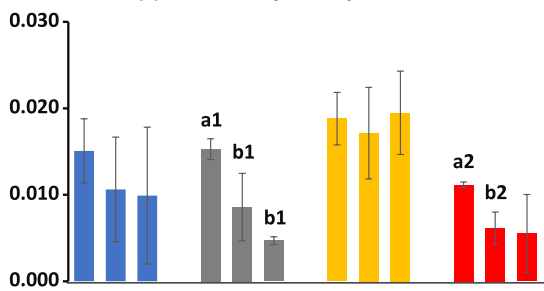

(i) Ectomycorrhizal

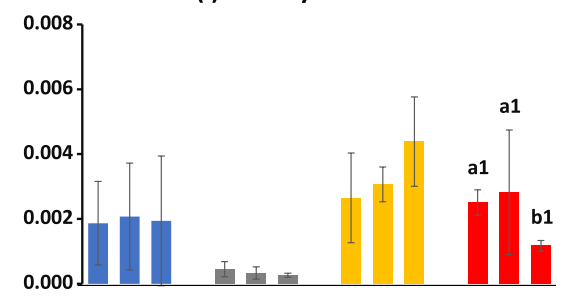

(I) Potential nitrification rate

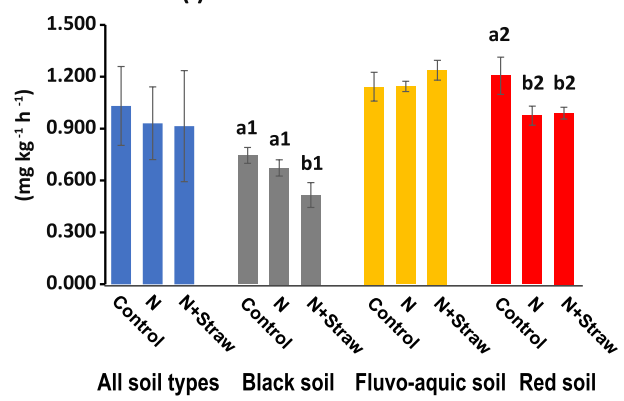

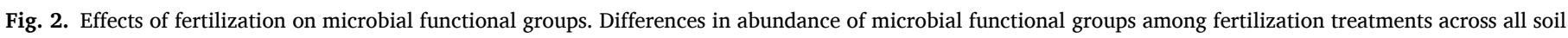

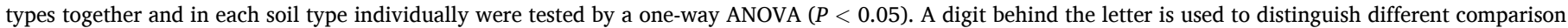

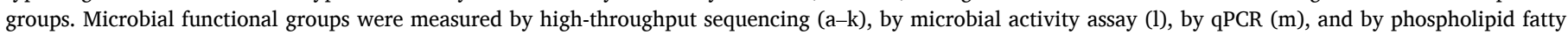
acids (PLFA; n). Control: no nitrogen addition; N: Nitrogen addition; $\mathrm{N}+$ Straw: Nitrogen plus straw addition.

treatments in the black soil and decreased by the $\mathrm{N}$ treatment in the red soil $(P<0.05$, Fig. 2 f). Potentially human pathogenic pneumonia bacteria, and all potentially human pathogenic bacteria were decreased by the $\mathrm{N}$ and $\mathrm{N}+$ Straw treatments in the black soil $(P<0.05$, Fig. $2 \mathrm{~g}$ and h). Ectomycorrhizal and symbiotrophic fungi were decreased by the $\mathrm{N}+$ Straw treatment in the black soil $(P<0.05$, Fig. $2 \mathrm{i}$ and $\mathrm{j})$. Phagotrophic protists were decreased by the $\mathrm{N}+$ Straw treatment in the black and red soils and decreased by the $\mathrm{N}$ and $\mathrm{N}+$ Straw treatments in the fluvo-aquic soil $(P<0.05$, Fig. 2k).

Microbial functional assays illustrated that the potential nitrification rate (PNR) was decreased by the $\mathrm{N}+$ Straw treatment in the black soil and by the $\mathrm{N}$ and $\mathrm{N}+$ Straw treatments in the red soil $(P<0.05$, Fig. 21$)$. 
The absolute abundance of Chlorophyta was increased by the $\mathrm{N}+$ Straw treatment in the black soil $(P<0.05$, Fig. $2 \mathrm{~m})$. The biomass of AMF was decreased by the $\mathrm{N}$ and $\mathrm{N}+$ Straw treatments in the black soil but increased by the $\mathrm{N}+$ Straw treatment in the red soil $(P<0.05$, Fig. $2 \mathrm{n})$.

\subsection{Underlying drivers of functional changes of the soil microbiome to fertilization}

Random forest analysis showed that $\mathrm{NO}_{3}^{-}-\mathrm{N}$, and climatic and

(a) The importance of significant environmental variables

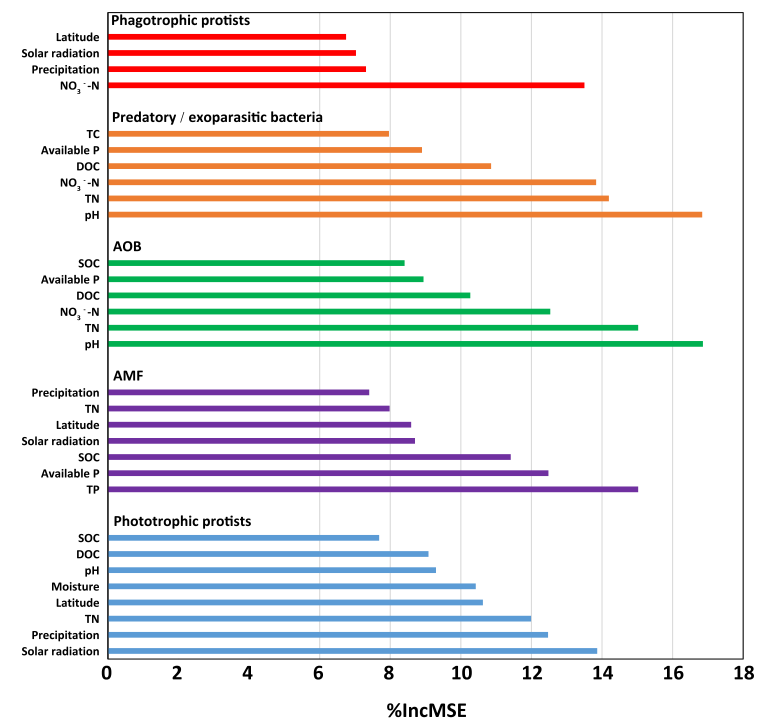

(b) Relationships between microbial functional groups and environment variables

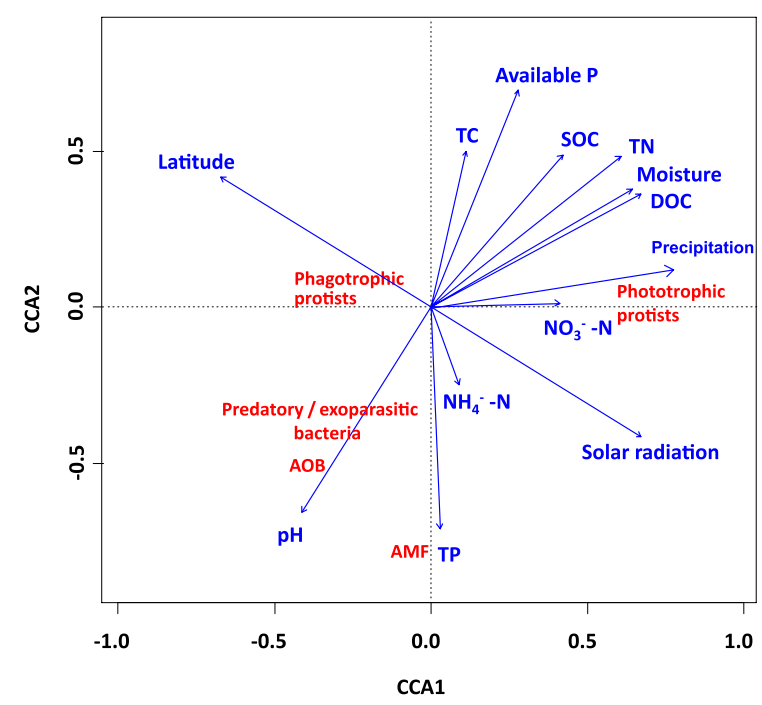

Fig. 3. Random forest and canonical correspondence analyses revealing environmental factors that determine soil microbial functional groups. (a) The importance of environmental variables was determined by random forest analysis using an increase in the mean square error (InMSE). Observed significant $(P<0.05)$ environmental variables determining phagotrophic protists (red), predatory/exoparasitic bacteria (orange), AOB (green), AMF (violet), and phototrophic protists (blue) are shown. (b) Canonical correspondence analysis showing microbial functional groups in red and environmental factors in blue. Microbial functional groups located in the forward direction of the arrow of the environmental factor imply positive relationship between the microbial functional group and the environmental factor, and vice versa. (For interpretation of the references to color in this figure legend, the reader is referred to the Web version of this article.) geographic factors (precipitation, solar radiation and latitude) affected the abundance of soil phagotrophic protists $(P<0.05$, Fig. 3a). More specifically, phagotrophic protists were negatively structured by $\mathrm{NO}_{3}^{-}$ $-\mathrm{N}$ and precipitation (Fig. 3b). The relative abundance of $\mathrm{AOB}$ and predatory/exoparasitic bacteria were changed by $\mathrm{pH}, \mathrm{TN}$ and $\mathrm{NO}_{3}^{-}-\mathrm{N}$ $\left(P<0.05\right.$, Fig. 3a). Soil $\mathrm{pH}$ positively shaped and $\mathrm{NO}_{3}^{-}-\mathrm{N}$ negatively influenced $\mathrm{AOB}$ and predatory/exoparasitic bacteria in soil (Fig. 3b). However, the climatic and geographic factors (solar radiation, latitude), water availability related parameters (precipitation, soil moisture) and organic carbon (SOC, DOC) all with the exception of latitude positively affected the abundance of phototrophic protists $(P<0.05$, Fig. 3a and b). AMF were mostly influenced by phosphorus-related environmental factors (TP, available $\mathrm{P}$ ) and precipitation $(P<0.05$, Fig. 3a), while being negatively structured by available $\mathrm{P}$ and soil water availability (precipitation, soil moisture) (Fig. 3b).

Structural equation modelling (SEM) constructed to decipher potential links among these susceptible abiotic (Fig. 1) and biotic (Fig. 2) factors in both black and red soils revealed high explanatory power of the model including $\mathrm{pH}, \mathrm{AOB}$, predatory/exoparasitic bacteria and phagotrophic protists $(52 \%, 38 \%, 86 \%$ and $70 \%$, respectively, Fig. 4). SEM results on two soil types were supported across all soils by random forest analysis. These showed that abiotic factors including the enrichment of $\mathrm{NO}_{3}^{-}-\mathrm{N}$ by nitrogen fertilizations substantially explained the observed reductions in the microbial functional groups, while soil $\mathrm{pH}$ was positively linked with the relative abundance of phagotrophic protists (Fig. 4). Specifically, the application of nitrogen fertilizers increased $\mathrm{NO}_{3}^{-}-\mathrm{N}$, leading to decreased soil $\mathrm{pH}(P<0.05$, Fig. 4), which explained the reductions in phagotrophic protists $(P<0.05$, Fig. 4). Furthermore, reductions of AOB (0.811) were shown to be more important than $\mathrm{NO}_{3}^{-}-\mathrm{N}(0.665)$ and $\mathrm{pH}(0.142)$ in explaining decreases of predatory/exoparasitic bacteria $(P<0.05$, Fig. 4); reductions of predatory/exoparasitic bacteria (0.772) were shown to be more important than $\mathrm{pH}(0.690), \mathrm{NO}_{3}^{-}-\mathrm{N}(0.620)$, and $\mathrm{AOB}(0.045)$ in explaining decreases of phagotrophic protists $(P<0.05$, Fig. 4$)$.

\section{Discussion}

We here provide a unique overview of functional changes in the soil microbiome in responses to fertilization practices, that extends our previous findings on fertilization-induced taxonomic changes (Zhao et al., 2019). Overall, we show that fertilization only changed phagotrophic protists across three soil types, which largely rejects our first hypothesis. We found that fertilization-induced abiotic changes alter microbial functions that depend on the soil and environmental conditions. Changes in phagotrophic protists might lead to long-term effects on bacterial and fungal functioning as these microbial functions are often observed to change over longer timescales (Fierer et al., 2012; Ai et al., 2013; Su et al., 2015; Babin et al., 2019; Huang et al., 2019; Li et al., 2020). Microbial functioning is, however, not guaranteed to change over time as shown by some long-term nitrogen fertilization studies (Bissett et al., 2011; Pan et al., 2014). Variable patterns could be attributed to differences in the dose of nitrogen addition, time of sampling, soil type, and cropping system (Geisseler and Scow, 2014). Our findings extend knowledge on the key role of edaphic and climatic factors in shaping the taxonomic composition of bacterial, fungal, and protist communities (Fierer and Jackson, 2006; Bates et al., 2013; Tedersoo et al., 2014) to the functional level.

The observed general negative effects of nitrogen fertilizers on soil phagotrophic protists could be attributed to a profound enrichment of ammonia (Angus et al., 2014). High ammonia concentrations might have toxic effects on protists as ammonia can pass through cell membranes and induce cell disruption (Puigagut et al., 2005; Klimek et al., 2012; Angus et al., 2014). Fertilization-induced nitrate increases along with soil acidification could also indirectly suppress phagotrophic protists (Angus et al., 2014). The suppression of phagotrophic protists by fertilization supports previous studies focusing on specific taxonomic 


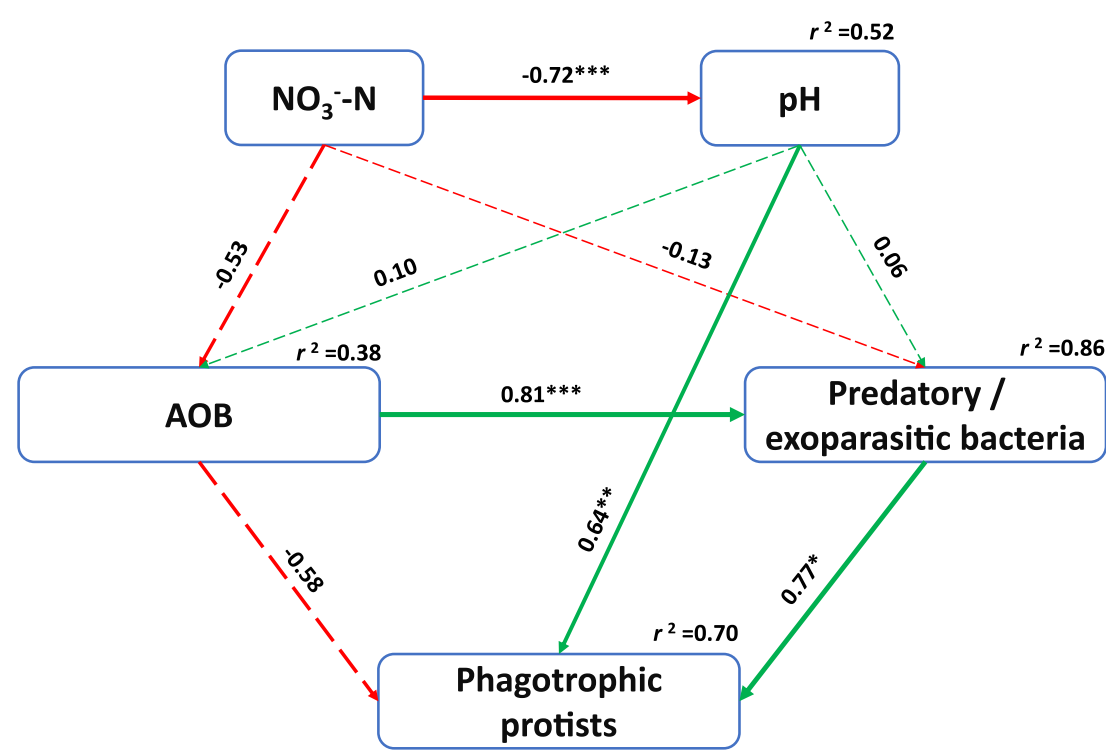

Fig. 4. Abiotic and biotic links between microbial functional groups in the acidic soils. A structural equation model (SEM) was constructed based on variables in the black and red soils. Continuous and dashed arrows represent significant and nonsignificant relationships, respectively. Numbers adjacent to arrows represent path coefficients, with arrow widths being proportional to the degree of path coefficients. Green and red arrows indicate positive and negative relationships, respectively. $r^{2}$ values indicate the proportion of variance explained for each variable. Significance levels are denoted with $* P<0.05,{ }^{*} * P<$ $0.01, * * * P<0.001$. Standardized total effects (direct plus indirect effects) calculated by the SEM are displayed below the SEM. Chi-square $\left(\chi^{2}=0.005\right)$, probability level $(P=0.946)$, goodness-of-fit index $(\mathrm{GFI}=1.000)$, Akaike information criteria (AIC = 28.005), and root-mean-square errors of approximation (RMSEA $=0.000$ ) indicate that our data matches the hypothetical model. (For interpretation of the references to color in this figure legend, the reader is referred to the Web version of this article.)

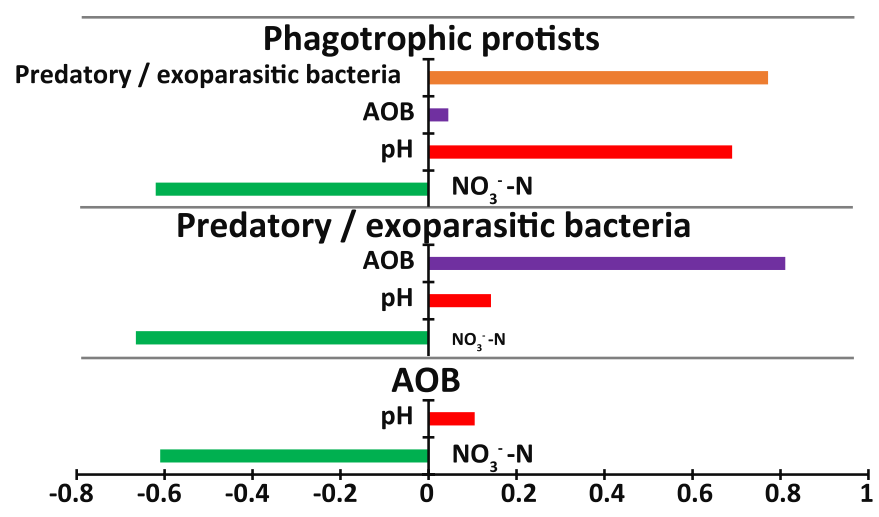

\section{Standardized total effects on microbial functional groups from SEM}

groups of protists, illustrating that abundances of testate amoebae, ciliates and overall phagotrophic protists were reduced by nitrogen inputs in peatland (Gilbert et al., 1998), grassland (Eisenhauer et al., 2012) and agricultural soil (Angus et al., 2014). The observed strongest effects on higher trophic-level phagotrophic protists compared with bacterial and fungal functional groups are in line with the trophic sensitivity hypothesis stating that higher trophic levels are more susceptible to changes than lower trophic levels (Hedlund et al., 2004; Wang et al., 2019a). It is increasingly shown that protists can be more susceptible to changes than their prey such as under increasing plant diversity (Scherber et al., 2010) or as indicators of plant health (Xiong et al., 2020). Protists occupy a central position in soil food-webs, with especially phagotrophic protists being intimately associated with multiple processes in nutrient cycling by feeding on microbial prey (Pogue and Gilbride, 2007; Murase and Frenzel, 2008; Valencia et al., 2018). As phagotrophic protists represent by far most protists in soils, both in this study and in soils across global soils (Oliverio et al., 2020), the observed fertilization-induced of this key functional group might have dramatic cascading effects on soil functioning. For example, associated ecological processes in soil systems, particularly nutrient cycling at longer temporal scales could be affected.

In support of our second hypothesis, we found that soil type altered fertilizer effects on several microbial functions. For example, observed soil type specific changes by fertilizers on AMF have been found before (Shen et al., 2014) and can be attributed to differences in soil phosphorus (Parniske, 2008) and water availability (Xiang et al., 2016).
Variable sunlight (Lukesova and Hoffmann, 1996) and precipitation (Kidron et al., 2012) might have affected Chlorophyta. Little effects on microbial functioning in fluvo-aquic alkaline soils (Ai et al., 2013) might be attributed to the buffering capacity against fertilization-induced acidification as found in the acidic soils. The tight influence of $\mathrm{pH}$ on bacterial community composition (Delgado-Baquerizo et al., 2018) explains the absence of effects of fertilization on bacterial functional groups in this $\mathrm{pH}$-buffered alkaline soil. Our results on AOB confirm previous findings, which reported that nitrogen fertilization-induced soil acidification decreased the abundance of AOB in acidic soils ( $\mathrm{He}$ et al., 2007; Yao et al., 2011; Zhong et al., 2016). These observed reductions of AOB by fertilization in the black and red soils could be explained by a limitation of substrate for AOB as ionization of ammonia to ammonium promoted by soil acidification at lower $\mathrm{pH}(<5.5)$ (Gubry-Rangin et al., 2010; Lehtovirta-Morley et al., 2011; Zhang et al., 2012). The reductions of predatory/exoparasitic bacteria by fertilization were also consistent with a previous study, which illustrated that $\mathrm{pH}$ determined predatory bacteria (myxobacteria) abundance and cell density after long-term nitrogen fertilization (Wang et al., 2019b).

Interestingly, we found that potential biotic interactions might explain fertilization-induced changes in functional groups in the acidic soils. For example, changes in AOB were tightly linked to changes of predatory/exoparasitic bacteria. Both groups likely respond to similar changes in their surrounding habitat as shown before (Yao et al., 2011; Wang et al., 2019b). Predatory bacteria prey on a diverse range of bacteria (Morgan et al., 2010; Petters et al., 2018) and therefore reduce 
especially the bacteria that are more dominant and easier to find. These predatory bacteria are also selective in their prey choice (Morgan et al., 2010), and might therefore promote AOB through preying on their bacterial competitors. A strong positive link between predatory/exoparasitic bacteria with phagotrophic protists might be explained by the fact that both predator groups follow abundances of their main prey: bacteria (Geisen et al., 2018; Petters et al., 2018).

\section{Conclusions}

Our research provides a cumulative map of the functional composition of agricultural soil microbiomes in response to fertilization in different agricultural soil types. The observed alteration in functional groups within the soil microbiome sheds light on potentially relevant ecological functions that change under fertilization in agricultural systems, with the unique finding of phagotrophic protists being most strongly suppressed by fertilization across soil types. Further research should experimentally confirm the direct influence of fertilizers on protists and how that translates to other microbial functions. Indeed, by considering the importance of microbial predators in different soils, we might soon be able to reduce fertilizer inputs due to increased biotic nutrient remineralization processes.

\section{Declaration of competing interest}

The authors declare that they have no known competing financial interests or personal relationships that could have appeared to influence the work reported in this paper.

\section{Acknowledgments}

This work was financially supported by the Strategic Priority Research Program of the Chinese Academy of Sciences (XDB15020200). Stefan Geisen was supported by an NWO-VENI grant from the Netherlands Organisation for Scientific Research (016.Veni.181.078). We thank Prof. Yan-Lai Han, Wen-Xue Wei, Yun-Ting Fang, and Dr. PeiPei Li for cooperation and assistance in the field experimentation, PengXia Xu for laboratory work, and Bing Han and Jun-Tao Wang for their assistances in data processing.

\section{Appendix A. Supplementary data}

Supplementary data to this article can be found online at https://doi. org/10.1016/j.soilbio.2020.107863.

\section{Authors' contributions}

JZH, ZBZ, LMZ and SG designed the research; ZQ, CFW, RS and LMZ managed the field trial stations; ZBZ, ZQ, RS and CFW sampled soils, ZBZ conducted the laboratory analyses, ZBZ, ZQ and RS collected the raw data, ZBZ and SG performed the data processes; ZBZ, SG, and JZH wrote the manuscript. All authors read and approved the final manuscript.

\section{References}

Ai, C., Liang, G.Q., Sun, J.W., Wang, X.B., He, P., Zhou, W., 2013. Different roles of rhizosphere effect and long-term fertilization in the activity and community structure of ammonia oxidizers in a calcareous fluvo-aquic soil. Soil Biology and Biochemistry 57, 30-42.

Allison, S.D., Hanson, C.A., Treseder, K.K., 2007. Nitrogen fertilization reduces diversity and alters community structure of active fungi in boreal ecosystems. Soil Biology and Biochemistry 39, 1878-1887.

Altieri, M.A., Nicholls, C.I., 2003. Soil fertility management and insect pests: harmonizing soil and plant health in agroecosystems. Soil and Tillage Research 72 203-211.

Angus, J.F., Gupta, V.V.S.R., Pitson, G.D., Good, A.J., 2014. Effects of banded ammonia and urea fertiliser on soil properties and the growth and yield of wheat. Crop \& Pasture Science 65, 337-352.
Babin, D., Deubel, A., Jacquiod, S., Sorensen, S.J., Geistlinger, J., Grosch, R., Smalla, K., 2019. Impact of long-term agricultural management practices on soil prokaryotic communities. Soil Biology and Biochemistry 129, 17-28.

Bates, S.T., Berg-Lyons, D., Caporaso, J.G., Walters, W.A., Knight, R., Fierer, N., 2011 Examining the global distribution of dominant archaeal populations in soil. The ISME Journal 5, 908-917.

Bates, S.T., Clemente, J.C., Flores, G.E., Walters, W.A., Parfrey, L.W., Knight, R., Fierer, N., 2013. Global biogeography of highly diverse protistan communities in soil. The ISME Journal 7, 652-659.

Bell, T.H., Hassan, S.E., Lauron-Moreau, A., Al-Otaibi, F., Hijri, M., Yergeau, E., StArnaud, M., 2014. Linkage between bacterial and fungal rhizosphere communities in hydrocarbon-contaminated soils is related to plant phylogeny. The ISME Journal 8, $331-343$.

Bissett, A., Richardson, A.E., Baker, G., Thrall, P.H., 2011. Long-term land use effects on soil microbial community structure and function. Applied Soil Ecology 51, 66-78.

Breiman, L., 2001. Random forests. Machine Learning 45, 5-32.

Caporaso, J.G., Kuczynski, J., Stombaugh, J., Bittinger, K., Bushman, F.D., Costello, E.K., Fierer, N., Pena, A.G., Goodrich, J.K., Gordon, J.I., Huttley, G.A., Kelley, S.T., Knights, D., Koenig, J.E., Ley, R.E., Lozupone, C.A., McDonald, D., Muegge, B.D., Pirrung, M., Reeder, J., Sevinsky, J.R., Turnbaugh, P.J., Walters, W.A., Widmann, J., Yatsunenko, T., Zaneveld, J., Knight, R., 2010. QIIME allows analysis of highthroughput community sequencing data. Nature Methods 7, 335-336.

Cheng, B.S., Komoroske, L.M., Grosholz, E.D., 2017. Trophic sensitivity of invasive predator and native prey interactions: integrating environmental context and climate change. Functional Ecology 31, 642-652.

Delgado-Baquerizo, M., Bissett, A., Eldridge, D.J., Maestre, F.T., He, J.-Z., Wang, J.-T. Hamonts, K., Liu, Y.-R., Singh, B.K., Fierer, N., 2017. Palaeoclimate explains a unique proportion of the global variation in soil bacterial communities. Nature Ecology \& Evolution 1, 1339-1347.

Delgado-Baquerizo, M., Maestre, F.T., Reich, P.B., Jeffries, T.C., Gaitan, J.J., Encinar, D., Berdugo, M., Campbell, C.D., Singh, B.K., 2016. Microbial diversity drives multifunctionality in terrestrial ecosystems. Nature Communications 7, 10541.

Delgado-Baquerizo, M., Oliverio, A.M., Brewer, T.E., Benavent-Gonzalez, A., Eldridge, D. J., Bardgett, R.D., Maestre, F.T., Singh, B.K., Fierer, N., 2018. A global atlas of the dominant bacteria found in soil. Science 359, 320.

Dick, W.A., Tabatabai, M.A., 1977. Alkaline oxidation method for determination of total phosphorus in soils. Soil Science Society of America Journal 41, 511-514.

Drigo, B., Pijl, A.S., Duyts, H., Kielak, A.M., Gamper, H.A., Houtekamer, M.J., Boschker, H.T., Bodelier, P.L., Whiteley, A.S., van Veen, J.A., Kowalchuk, G.A., 2010. Shifting carbon flow from roots into associated microbial communities in response to elevated atmospheric $\mathrm{CO}_{2}$. Proceedings of the National Academy of Sciences of the United States of America 107, 10938-10942.

Edgar, R.C., 2013. UPARSE: highly accurate OTU sequences from microbial amplicon reads. Nature Methods 10, 996-998.

Eisenhauer, N., Cesarz, S., Koller, R., Worm, K., Reich, P.B., 2012. Global change belowground: impacts of elevated $\mathrm{CO}_{2}$, nitrogen, and summer drought on soil food webs and biodiversity. Global Change Biology 18, 435-447.

Erisman, J.W., Galloway, J.N., Seitzinger, S., Bleeker, A., Dise, N.B., Petrescu, A.M.R., Leach, A.M., de Vries, W., 2013. Consequences of human modification of the global nitrogen cycle. Philosophical Transactions of the Royal Society B: Biological Sciences $368,9$.

Fierer, N., 2017. Embracing the unknown: disentangling the complexities of the soil microbiome. Nature Reviews Microbiology 15, 579-590.

Fierer, N., Jackson, R.B., 2006. The diversity and biogeography of soil bacterial communities. Proceedings of the National Academy of Sciences of the United States of America 103, 626-631.

Fierer, N., Lauber, C.L., Ramirez, K.S., Zaneveld, J., Bradford, M.A., Knight, R., 2012. Comparative metagenomic, phylogenetic and physiological analyses of soil microbial communities across nitrogen gradients. The ISME Journal 6, 1007-1017.

Geisen, S., Mitchell, E.A.D., Adl, S., Bonkowski, M., Dunthorn, M., Ekelund, F., Fernandez, L.D., Jousset, A., Krashevska, V., Singer, D., Spiegel, F.W., Walochnik, J., Lara, E., 2018. Soil protists: a fertile frontier in soil biology research. FEMS Microbiology Reviews 42, 293-323.

Geisseler, D., Scow, K.M., 2014. Long-term effects of mineral fertilizers on soil microorganisms - a review. Soil Biology and Biochemistry 75, 54-63.

Gilbert, D., Amblard, C., Bourdier, G., Francez, A.J., 1998. Short-term effect of nitrogen enrichment on the microbial communities of a peatland. Hydrobiologia 374, $111-119$.

Grace, J.B., Keeley, J.E., 2006. A structural equation model analysis of postfire plant diversity in California shrublands. Ecological Applications 16, 503-514.

Gubry-Rangin, C., Nicol, G.W., Prosser, J.I., 2010. Archaea rather than bacteria control nitrification in two agricultural acidic soils. FEMS Microbiology Ecology 74, 566-574.

Guillou, L., Bachar, D., Audic, S., Bass, D., Berney, C., Bittner, L., Boutte, C., Burgaud, G., de Vargas, C., Decelle, J., Del Campo, J., Dolan, J.R., Dunthorn, M., Edvardsen, B., Holzmann, M., Kooistra, W.H., Lara, E., Le Bescot, N., Logares, R., Mahe, F., Massana, R., Montresor, M., Morard, R., Not, F., Pawlowski, J., Probert, I., Sauvadet, A.L., Siano, R., Stoeck, T., Vaulot, D., Zimmermann, P., Christen, R., 2013. The Protist Ribosomal Reference database (PR2): a catalog of unicellular eukaryote small sub-unit rRNA sequences with curated taxonomy. Nucleic Acids Research 41, D597-D604.

Hartman, K., van der Heijden, M.G.A., Wittwer, R.A., Banerjee, S., Walser, J.-C., Schlaeppi, K., 2018. Cropping practices manipulate abundance patterns of root and soil microbiome members paving the way to smart farming. Microbiome 6, 14.

He, J.Z., Shen, J.P., Zhang, L.M., Zhu, Y.G., Zheng, Y.M., Xu, M.G., Di, H., 2007. Quantitative analyses of the abundance and composition of ammonia-oxidizing 
bacteria and ammonia-oxidizing archaea of a Chinese upland red soil under longterm fertilization practices. Environmental Microbiology 9, 2364-2374.

Hedlund, K., Griffiths, B., Christensen, S., Scheu, S., Setala, H., Tscharntke, T., Verhoef, H., 2004. Trophic interactions in changing landscapes: responses of soil food webs. Basic and Applied Ecology 5, 495-503.

Horrigan, L., Lawrence, R.S., Walker, P., 2002. How sustainable agriculture can address the environmental and human health harms of industrial agriculture. Environmental Health Perspectives 110, 445-456.

Huang, Q., Wang, J.L., Wang, C., Wang, Q., 2019. The 19-years inorganic fertilization increased bacterial diversity and altered bacterial community composition and potential functions in a paddy soil. Applied Soil Ecology 144, 60-67.

Jiao, S., Xu, Y., Zhang, J., Lu, Y., 2019. Environmental filtering drives distinct continental atlases of soil archaea between dryland and wetland agricultura ecosystems. Microbiome 7, 15.

Kidron, G.J., Barinova, S., Vonshak, A., 2012. The effects of heavy winter rains and rare summer rains on biological soil crusts in the Negev Desert. Catena 95, 6-11.

Klimek, B., Fyda, J., Pajdak-Stos, A., Kocerba, W., Fialkowska, E., Sobczyk, M., 2012. Toxicity of ammonia nitrogen to ciliated protozoa Stentor coeruleus and Coleps hirtus isolated from activated sludge of wastewater treatment plants. Bulletin of Environmental Contamination and Toxicology 89, 975-977.

Kuypers, M.M.M., Marchant, H.K., Kartal, B., 2018. The microbial nitrogen-cycling network. Nature Reviews Microbiology 16, 263-276.

Lal, R., 2004. Soil carbon sequestration impacts on global climate change and food security. Science 304, 1623-1627.

Lehtovirta-Morley, L.E., Stoecker, K., Vilcinskas, A., Prosser, J.I., Nicol, G.W., 2011. Cultivation of an obligate acidophilic ammonia oxidizer from a nitrifying acid soil. Proceedings of the National Academy of Sciences of the United States of America 108, 15892-15897.

Li, J., Delgado-Baquerizo, M., Wang, J.-T., Hu, H.-W., Cai, Z.-J., Zhu, Y.-N., Singh, B.K., 2019. Fungal richness contributes to multifunctionality in boreal forest soil. Soil Biology and Biochemistry 136, 107526.

Li, Y.L., Tremblay, J., Bainard, L.D., Cade-Menun, B., Hamel, C., 2020. Long-term effects of nitrogen and phosphorus fertilization on soil microbial community structure and function under continuous wheat production. Environmental Microbiology 22 1066-1088.

Liang, F., Li, G.-t., Lin, Q.-m., Zhao, X.-r., 2014. Crop yield and soil properties in the first 3 Years after Biochar application to a calcareous soil. Journal of Integrative Agriculture 13, 525-532.

Long, X., Chen, C., Xu, Z., Oren, R., He, J.-Z., 2012. Abundance and community structure of ammonia-oxidizing bacteria and archaea in a temperate forest ecosystem under ten-years elevated $\mathrm{CO}_{2}$. Soil Biology and Biochemistry 46, 163-171.

Louca, S., Parfrey, L.W., Doebeli, M., 2016. Decoupling function and taxonomy in the global ocean microbiome. Science 353, 1272-1277.

Lukesova, A., Hoffmann, L., 1996. Soil algae from acid rain impacted forest areas of the Krusne hory Mts .1. Algal communities. Vegetatio 125, 123-136.

Morgan, A.D., MacLean, R.C., Hillesland, K.L., Velicer, G.J., 2010. Comparative analysis of myxococcus predation on soil bacteria. Applied and Environmental Microbiology $76,6920-6927$.

Murase, J., Frenzel, P., 2008. Selective grazing of methanotrophs by protozoa in a rice field soil. FEMS Microbiology Ecology 65, 408-414.

Nguyen, N.H., Song, Z., Bates, S.T., Branco, S., Tedersoo, L., Menke, J., Schilling, J.S., Kennedy, P.G., 2016. FUNGuild: an open annotation tool for parsing fungal community datasets by ecological guild. Fungal Ecology 20, 241-248.

Oliverio, A.M., Geisen, S., Delgado-Baquerizo, M., Maestre, F.T., Turner, B.L., Fierer, N., 2020. The global-scale distributions of soil protists and their contributions to belowground systems. Science Advances 6, eaax8787.

Pan, F., Li, Y., Chapman, S.J., Yao, H., 2016. Effect of rice straw application on microbial community and activity in paddy soil under different water status. Environmental Science and Pollution Research 23, 5941-5948.

Pan, Y., Cassman, N., de Hollander, M., Mendes, L.W., Korevaar, H., Geerts, R., van Veen, J.A., Kuramae, E.E., 2014. Impact of long-term N, P, K, and NPK fertilization on the composition and potential functions of the bacterial community in grassland soil. FEMS Microbiology Ecology 90, 195-205.

Parniske, M., 2008. Arbuscular mycorrhiza: the mother of plant root endosymbioses. Nature Reviews Microbiology 6, 763-775.

Petchey, O.L., McPhearson, P.T., Casey, T.M., Morin, P.J., 1999. Environmental warming alters food-web structure and ecosystem function. Nature 402, 69-72.

Petters, S., Söllinger, A., Bengtsson, M.M., Urich, T., 2018. The Soil Microbial Food Web Revisited with Metatranscriptomics - Predatory Myxobacteria as Keystone Taxon? bioRxiv, p. 373365.

Pogue, A.J., Gilbride, K.A., 2007. Impact of protozoan grazing on nitrification and the ammonia- and nitrite-oxidizing bacterial communities in activated sludge. Canadian Journal of Microbiology 53, 559-571.

Prosser, J.I., Nicol, G.W., 2012. Archaeal and bacterial ammonia-oxidisers in soil: the quest for niche specialisation and differentiation. Trends in Microbiology 20, 523-531.

Puigagut, J., Salvado, H., Garcia, J., 2005. Short-term harmful effects of ammonia nitrogen on activated sludge microfauna. Water Research 39, 4397-4404.

Quast, C. Pruesse, E., Yilmaz, P., Gerken, J., Schweer, T., Yarza, P., Peplies, J., Glockner, F.O., 2013. The SILVA ribosomal RNA gene database project: improved data processing and web-based tools. Nucleic Acids Research 41, D590-D596.

Rahmonov, O., Cabala, J., Bednarek, R., Rozek, D., Florkiewicz, A., 2015. Role OF soil algae ON the initial stages OF soil formation IN sandy polluted areas. Ecological Chemistry and Engineering S-Chemia I Inzynieria Ekologiczna S 22, 675-690.
Richardson, A.E., Barea, J.-M., McNeill, A.M., Prigent-Combaret, C., 2009. Acquisition of phosphorus and nitrogen in the rhizosphere and plant growth promotion by microorganisms. Plant and Soil 321, 305-339.

Rousk, J., Baath, E., Brookes, P.C., Lauber, C.L., Lozupone, C., Caporaso, J.G., Knight, R., Fierer, N., 2010. Soil bacterial and fungal communities across a pH gradient in an arable soil. The ISME Journal 4, 1340-1351.

Saleem, M., Moe, L.A., 2014. Multitrophic microbial interactions for eco- and agrobiotechnological processes: theory and practice. Trends in Biotechnology 32, 529-537.

Scherber, C., Eisenhauer, N., Weisser, W.W., Schmid, B., Voigt, W., Fischer, M., Schulze, E.-D., Roscher, C., Weigelt, A., Allan, E., Bessler, H., Bonkowski, M., Buchmann, N., Buscot, F., Clement, L.W., Ebeling, A., Engels, C., Halle, S., Kertscher, I., Klein, A.-M., Koller, R., Koenig, S., Kowalski, E., Kummer, V., Kuu, A., Lange, M., Lauterbach, D., Middelhoff, C., Migunova, V.D., Milcu, A., Mueller, R., Partsch, S., Petermann, J.S., Renker, C., Rottstock, T., Sabais, A., Scheu, S., Schumacher, J., Temperton, V.M., Tscharntke, T., 2010. Bottom-up effects of plant diversity on multitrophic interactions in a biodiversity experiment. Nature 468 , $553-556$.

Schulz-Bohm, K., Geisen, S., Wubs, E.R., Song, C., de Boer, W., Garbeva, P., 2017. The prey's scent - volatile organic compound mediated interactions between soil bacteria and their protist predators. The ISME Journal 11, 817-820.

Shade, A., 2017. Diversity is the question, not the answer. The ISME Journal 11, 1-6.

Shen, J.-P., Zhang, L.-M., Zhu, Y.-g., Zhang, J.-b., He, J.-z., 2008. Abundance and composition of ammonia-oxidizing bacteria and ammonia-oxidizing archaea communities of an alkaline sandy loam. Environmental Microbiology 10, 1601-1611.

Shen, R.C., Xu, M., Chi, Y.G., Yu, S., Wan, S.Q., 2014. Soil microbial responses to experimental warming and nitrogen addition in a temperate steppe of Northern China. Pedosphere 24, 427-436.

Stoeck, T., Bass, D., Nebel, M., Christen, R., Jones, M.D., Breiner, H.W., Richards, T.A., 2010. Multiple marker parallel tag environmental DNA sequencing reveals a highly complex eukaryotic community in marine anoxic water. Molecular Ecology 19 (Suppl. 1), 21-31.

Su, J.Q., Ding, L.J., Xue, K., Yao, H.Y., Quensen, J., Bai, S.J., Wei, W.X., Wu, J.S., Zhou, J. Z., Tiedje, J.M., Zhu, Y.G., 2015. Long-term balanced fertilization increases the soil microbial functional diversity in a phosphorus-limited paddy soil. Molecular Ecology 24, 136-150.

Tedersoo, L., Bahram, M., Polme, S., Koljalg, U., Yorou, N.S., Wijesundera, R., Villarreal Ruiz, L., Vasco-Palacios, A.M., Pham Quang, T., Suija, A., Smith, M.E., Sharp, C., Saluveer, E., Saitta, A., Rosas, M., Riit, T., Ratkowsky, D., Pritsch, K., Poldmaa, K., Piepenbring, M., Phosri, C., Peterson, M., Parts, K., Paertel, K., Otsing, E., Nouhra, E., Njouonkou, A.L., Nilsson, R.H., Morgado, L.N., Mayor, J., May, T.W., Majuakim, L., Lodge, D.J., Lee, S.S., Larsson, K.-H., Kohout, P., Hosaka, K., Hiiesalu, I., Henkel, T. W., Harend, H., Guo, L.-d., Greslebin, A., Grelet, G., Geml, J., Gates, G., Dunstan, W., Dunk, C., Drenkhan, R., Dearnaley, J., De Kesel, A., Tan, D., Chen, X., Buegger, F., Brearley, F.Q., Bonito, G., Anslan, S., Abell, S., Abarenkov, K., 2014. Global diversity and geography of soil fungi. Science 346, 1078.

Thakur, M.P., Geisen, S., 2019. Trophic regulations of the soil microbiome. Trends in Microbiology 27, 771-780.

Tilman, D., Balzer, C., Hill, J., Befort, B.L., 2011. Global food demand and the sustainable intensification of agriculture. Proceedings of the National Academy of Sciences of the United States of America 108, 20260-20264.

Tilman, D., Cassman, K.G., Matson, P.A., Naylor, R., Polasky, S., 2002. Agricultural sustainability and intensive production practices. Nature 418, 671-677.

Valencia, E., Gross, N., Quero, J.L., Carmona, C.P., Ochoa, V., Gozalo, B., DelgadoBaquerizo, M., Dumack, K., Hamonts, K., Singh, B.K., Bonkowski, M., Maestre, F.T., 2018. Cascading effects from plants to soil microorganisms explain how plant species richness and simulated climate change affect soil multifunctionality. Global Change Biology 24, 5642-5654.

van der Heijden, M.G.A., Bardgett, R.D., van Straalen, N.M., 2008. The unseen majority: soil microbes as drivers of plant diversity and productivity in terrestrial ecosystems. Ecology Letters 11, 296-310.

Voigt, W., Perner, J., Davis, A.J., Eggers, T., Schumacher, J., Bahrmann, R., Fabian, B., Heinrich, W., Kohler, G., Lichter, D., Marstaller, R., Sander, F.W., 2003. Trophic levels are differentially sensitive to climate. Ecology 84, 2444-2453.

Wagg, C., Bender, S.F., Widmer, F., van der Heijden, M.G., 2014. Soil biodiversity and soil community composition determine ecosystem multifunctionality. Proceedings of the National Academy of Sciences of the United States of America 111, 5266-5270.

Wang, B., Wu, L., Chen, D., Wu, Y., Hu, S., Li, L., Bai, Y., 2019a. Grazing simplifies soil micro-food webs and decouples their relationships with ecosystem functions in grasslands. Global Change Biology 1-11, 00.

Wang, J.T., Zheng, Y.M., Hu, H.W., Li, J., Zhang, L.M., Chen, B.D., Chen, W.P., He, J.Z., 2016. Coupling of soil prokaryotic diversity and plant diversity across latitudinal forest ecosystems. Scientific Reports 6, 19561.

Wang, W., Wang, N., Dang, K., Dai, W., Guan, L., Wang, B., Gao, J., Cui, Z., Dong, Y., Wang, H., 2019b. Long-term nitrogen application decreases the abundance and copy number of predatory myxobacteria and alters the myxobacterial community structure in the soil. The Science of the Total Environment 708, 135114.

Wessen, E., Hallin, S., 2011. Abundance of archaeal and bacterial ammonia oxidizers possible bioindicator for soil monitoring. Ecological Indicators 11, 1696-1698.

Widder, S., Allen, R.J., Pfeiffer, T., Curtis, T.P., Wiuf, C., Sloan, W.T., Cordero, O.X., Brown, S.P., Momeni, B., Shou, W., Kettle, H., Flint, H.J., Haas, A.F., Laroche, B., Kreft, J.-U., Rainey, P.B., Freilich, S., Schuster, S., Milferstedt, K., van der Meer, J.R., Grosskopf, T., Huisman, J., Free, A., Picioreanu, C., Quince, C., Klapper, I., Labarthe, S., Smets, B.F., Wang, H., Soyer, O.S., Isaac Newton Inst, F., 2016. 
Challenges in microbial ecology: building predictive understanding of community function and dynamics. The ISME Journal 10, 2557-2568.

Wild, S., 2016. Mapping Africa's soil microbiome. Nature 539, 152-152.

Xiang, D., Veresoglou, S.D., Rillig, M.C., Xu, T., Li, H., Hao, Z., Chen, B., 2016. Relative importance of individual climatic drivers shaping arbuscular mycorrhizal fungal communities. Microbial Ecology 72, 418-427.

Xiong, W., Song, Y., Yang, K., Gu, Y., Wei, Z., Kowalchuk, G.A., Xu, Y., Jousset, A., Shen, Q., Geisen, S., 2020. Rhizosphere protists are key determinants of plant health. Microbiome 8, 27.

Yao, H., Gao, Y., Nicol, G.W., Campbell, C.D., Prosser, J.I., Zhang, L., Han, W., Singh, B. K., 2011. Links between ammonia oxidizer community structure, abundance, and nitrification potential in acidic soils. Applied and Environmental Microbiology 77, 4618-4625.

Yuan, H.Z., Ge, T.D., Chen, C.Y., O’Donnell, A.G., Wu, J.S., 2012. Significant role for microbial autotrophy in the sequestration of soil carbon. Applied and Environmenta Microbiology 78, 2328-2336.

Zeng, J., Liu, X., Song, L., Lin, X., Zhang, H., Shen, C., Chu, H., 2016. Nitrogen fertilization directly affects soil bacterial diversity and indirectly affects bacterial community composition. Soil Biology and Biochemistry 92, 41-49.
Zhang, L.M., Hu, H.W., Shen, J.P., He, J.Z., 2012. Ammonia-oxidizing archaea have more important role than ammonia-oxidizing bacteria in ammonia oxidation of strongly acidic soils. The ISME Journal 6, 1032-1045.

Zhao, Z.-B., He, J.-Z., Geisen, S., Han, L.-L., Wang, J.-T., Shen, J.-P., Wei, W.-X., Fang, Y.T., Li, P.-P., Zhang, L.-M., 2019. Protist communities are more sensitive to nitrogen fertilization than other microorganisms in diverse agricultural soils. Microbiome 7 , 33.

Zhong, W.H., Bian, B.Y., Gao, N., Min, J., Shi, W.M., Lin, X.G., Shen, W.S., 2016. Nitrogen fertilization induced changes in ammonia oxidation are attributable mostly to bacteria rather than archaea in greenhouse-based high $\mathrm{N}$ input vegetable soil. Soil Biology and Biochemistry 93, 150-159.

Zhu, C., Tian, G., Luo, G., Kong, Y., Guo, J., Wang, M., Guo, S., Ling, N., Shen, Q., 2018. $\mathrm{N}$-fertilizer-driven association between the arbuscular mycorrhizal fungal community and diazotrophic community impacts wheat yield. Agriculture, Ecosystems \& Environment 254, 191-201.

Zhu, F., Massana, R., Not, F., Marie, D., Vaulot, D., 2005. Mapping of picoeucaryotes in marine ecosystems with quantitative PCR of the $18 \mathrm{~S}$ rRNA gene. FEMS Microbiology Ecology 52, 79-92. 